Vol.8, Issue 7, pp.9-17, August 2020

Published by $\boldsymbol{E C R T D}-\boldsymbol{U K}$

Print ISSN: ISSN 2054-6351: Online ISSN: ISSN 2054-636X

\title{
Perception of Teachers and Principal on the Extent the Innovations in Science Curriculum is managed to Achieve Sustainable Development Goals among Senior Secondary School in Ikwuano LGA of Abia
}

\author{
Eucharia Ada Ike \& Edith Ezinwanyi Nwosu \\ Department of Educational Foundation. \\ College Of Education. \\ Micheal Okpara University Of Agriculture,Umudike.
}

\begin{abstract}
The study examined the perception of teachers and principal on the extent the innovations in science curriculum is managed to achieve sustainable development goals among senior secondary school in Ikwuano LGA of Abia. Two research questions and one hypothesis were raised to guide the study. The design for the study is a descriptive survey design, the area of the study is Ikwuano LGA and the population for the study consists of all principals and teachers in senior secondary school in Ikwuano LGA. The sample for the study consists of 100 teachers and 20 Principals. The instrument for data collection was a researcher structured questionnaire tagged "PTPISCMASDGQ" perception of teachers and principal on the extent innovations in science curriculum is managed to achieve sustainable development goals questionnaire. Content and face validity of the instrument was determined by administering the instrument to two lecturers in the department of Educational Management from the College of Education, Michael Okpara University of Agriculture. The reliability of the instrument was determined using Cronbach Alpha and it yielded a coefficient 0.78 . The data were analyzed using Mean and standard deviation while T-test. The results obtained from the study reveals that innovation in schools were no adequate for global competitiveness. It was recommended that process of planning educational change and innovation in science curriculum in Nigeria, should give the issues of training and retraining of teachers' optimal consideration amongst others.
\end{abstract}

KEYWORDS; innovation, curriculum, science education, sustainable development goals

\section{INTRODUCTION}

Curriculum is a particular form of specification about the practice of teaching. It is not a package of materials or syllabus of ground to be covered rather it is a way of translating any educational idea into a hypothesis testable in practice. It invites critical testing rather than acceptance (Stenhouse, 2005). Furthermore, curriculum is said to be a specification about the practice of teaching which involves pragmatic efficacy of the learners' experiences. Experience as a general concept comprises knowledge of or skill of something or some events gained through involvement in or exposure to that thing or event. In this wise, curriculum is an important element of education in which overall objectives of education depend largely on the nature of the curriculum (NERDC, 2004). 
Curriculum experts have argued that curriculum making either at the level of development, design, implementation or reformation needs the inputs of critical stakeholders if it is to be relevant, meaningful and adequate to meet the needs of the people for whom it has been put together. The need to adjust to changes of man insatiable need leads to innovation, which may be seen as a new thing added to the old or existing thing, thus Agabi in Agabi and Okorie(2002) defined innovation as positive planned and specific changes that are initiated to facilitate the achievement of some defined goals. Educational innovation is defined as planned changes in the educational objectives, policies, programmes, methods or practices within the intent of improving educational goal achievement (Otaru, 2015). Educational innovation refers to an improvement on the current level of education with a view of achieving set target. Ughamadu in Uyovwi (2006) maintained that curriculum innovation is quite vital as it enables education practices to change from time to time so as to reflect the consequent changes in the society. Provides the mean of trying new research findings enables classroom teacher to solve some instructional problems that they occasionally encounter in the teaching learning setting. Enables classroom teachers to acquire new knowledge that will make them more effective and productive. Summarily curriculum innovations are directed towards improving performance of the school system so as to be result oriented. Hence any innovation introduced into the school curriculum must take into consideration the school system of the school.

Innovations are used to modify some features of the educational system. The 9-3-4 system is a modification of the 6-3-3-4 system. Due to ever increasing society problems arising from climate change, unemployment, economic recession, government all over the world seeks o modify her curriculum to cater for these changes, for example in the year 2000, 189 countries collectively adopted what later become global economic development blueprint as the Millennium Development Goals (MDGs). The eight millennium Development Goals (MDGs) aim to eradicate extreme poverty and hunger; achieve universal basic primary education; promote gender equality and empower women; reduce child mortality; improve maternal health; and develop global partnership for development by the target date of 2015,(Kale, 2013), at the end of 2015 the MDGs where changes to SDGs with more goals of which BEC is inclusive Universal Basic Education is one of the cardinal goal out of the eight goals of the (MDGs) in which urgent and proactive measure and action needed to take. Universal Basic Education (UBE) is not the first of its kind in the measures toward achieving basic education and national development in Nigeria. The new revised 9-year Basic Education Curriculum is for 9-year of continuous schooling. Its implementation started in September, 2008 in all public and private primary and junior secondary schools in the country. This is to allow for a gradual and systematic phase out of the old curricula. However, the new revised 9-year BEC has a 3 - level structure: Lower level Primary 1-3, Middle level 4-6 and Upper level J.S.S 1-3. The philosophy of 9-year BEC entails that every learner who has gone through 9-year of basic education should have acquired appropriate level of literacy, numeracy, manipulate, communicative and life-skills, as well as the ethical, moral and civil values needed for laying a solid foundation for life-long learning as a basis for scientific and reflective thinking (NERDC 2008). 
The Universal Basic Education (UBE) program in Nigeria is a compulsory access to a nine-year basic education launched by the Federal Government to eradicate illiteracy, ignorance and poverty. It's meant to stimulate and accelerate national development, political consciousness and economic self-reliance (Ebenuwa - Okoh,2012). One begins to wonder how well these changes in curriculum has helped in achieving Sustainable Developmental Goals. This study therefore aimed at finding out whether the findings would fall in line with the findings in Owerri North Local Government Area of Imo State Nigeria. This is because no research in this area of study has been carried out in Ikwuano L.G.A of Abia State Nigeria.

\section{Statement of Problem}

The desire of every nation is to produce curriculum that will cater for the needs of her populace, thus curriculum is viewed as all the experienced or activities provided under the auspices of school to bring about a change in the learner in the desired direction, thus for there to be meaning full change in the life of a students, the curriculum has to be flexible to accommodate political and economics and changes.

Curriculum innovations is germane in order to meet the aspiration of the ever changing society of today, these changes are both in methodology and content of the subject matter employers of labour argue that most product of even tertiary education lack basic skill to do their job hence need retraining that makes cost to doing business expensive (Ike, 2017) if this ascertain is true for the today education, then what is the fate of our secondary school student in the labour market $o$ achieving sustainable development goals. The innovation in science, technical and vocation education is geared towards making product of secondary self-reliant when exposed techniques such as computer assisted instruction, computer based learner, skill acquisition in devise crafts etc which was differ from the old traditional teacher centered learning.

A National wide monitoring exercise on the implementation of the revised 9-year BEC carried out 12th January 2015 to 16th January 2015, it was reported that teachers' in some parts of the country are not still aware of the innovations in curriculum. For there to be progress and actualization of sustainable development goals there is need to know the perception of key players of the curriculum implementation and investigate into how well human and material resources are well managed by stakeholders to achieving the set goals in curriculum. Thus the researcher intends to investigate on the perception of teacher and principals on the extent to which innovation in our curriculum well managed o achieving sustainable development goals of students in secondary school to Ikwuano L.G.A of Abia State.

\section{Research Questions}

The following research questions are raised to guide the study

1. To what extent is the new science curriculum managed to achieve sustainable development from teachers' perception?

2. To what extent is the new science curriculum managed to achieve sustainable development from Principals perception? 


\section{Hypothesis}

$\mathrm{HO}_{1}$ There is no significance difference in the mean ratings of teachers and principals on the extent to the new science curriculum managed to achieve sustainable development.

\section{Theoretical Framework}

This study is predicated on Functional Curriculum Theory which emphasizes that learner should have a world pool of knowledge, ideas, inventions, human and financial capitals and become fully participating member of the global economy. The curriculum is a tripartite in nature and practical. According to Obanya (2004), the functional curriculum theory could be achieved by following these steps: a) Developing the deepest sense of pride in being African through a deep understanding of the pride of Africa, the mother tongue or community language, the African world view, Africa's contribution to world view, Africa's contribution to world civilization over the ages, the nature and literature of Africa, past and present contemporary African's plan for its future in the emerging global community. b) Access to a wide world of people, knowledge, techniques, ideas and practices, the official language and their literature, mathematics, science and technology, information tools and methods of social analysis, western and oriental philosophies and religion. c) Personal development for contribution to social transformation and vocational activities, entrepreneurship, creativity, communication and interpersonal conduct and self-awareness among others. These three goals should be pushed simultaneously from the beginning with their horizons broadcasting in responses to the level of maturity of the learner. Elements from any of the goals can also be utilized to inject functional value to existing programmes. Obanya construes functional content education as the situation in which the child is growing and the world he/she is going to live in should determine the way education is carried out, including what is taught and how it is being taught and learned. It is on this basis, the paper elaborates on how the innovation is germane in the curriculum to accommodate the ever changing needs and aspiration of the society and also could be used to develop individual learner towards increased productivity and improved quality of life. Thus, this paper defines innovative curriculum as the introducing a number of pathways through key changes eg 6334 to 934 in order to meet the needs of learners of all abilities and interests developing learners learning skills in order to achieve sustainable development goals and to compete favorably with other students from other advance nations.

\section{METHODOLOGY}

The design for the study is a descriptive survey design, the population for the study consist of 208 teachers and 23 principals in Ikwuano L.G.A of Abia State. The sample for the study consist of 100 teachers and 20 principals. Systematic random sampling technique was used to select 5 schools out of the 15 secondary that make up Ikwuano. In the second stage simple random sampling was used to select 20 teachers from each of the selected 5 school. Purposive sampling technical was used to select 20 school principal. The instruments for data collection is a researcher structured questionnaire tagged "PTPISCMASDGQ" perception of teachers and principal on the extent innovations in science curriculum is managed to achieve sustainable development goals questionnaire" The structure forma is a four point notifies liker scale, braving sections, A B and C. section A bio data information of respondents, B measures items on the extent to which innovation in school science curriculum are managed to achieve sustainable development from 
teachers point of view while section $\mathrm{C}$ measure perception of school principal on the extent to which innovation in school science curriculum are managed to achieve sustainable development. The validity of the instrument was determined two Lecturers in department of Education Management from Michael Okpara University of Agriculture.

The reliability of the instruments was determined using contact Alpha and it yield a coefficient of Arts. The data was collected secretly by the researcher. The method for data analysis includes the use of mean, standard deviation and t-test.

\section{RESULTS}

The results of his study are presented as follows

1. To what extent is innovation in curriculum managed to achieve sustainable development from teachers' perception?

Table 1 Mean ratings on the extent to which innovations in science curriculum managed to achieve sustainable development in Ikwuano LGA in Abia State.

\begin{tabular}{lllll}
\hline S/N & \multicolumn{1}{c}{ ITEMS } & SD & REMARKS \\
\hline 1 & $\begin{array}{l}\text { Effective teaching with adequate } \\
\text { instructional materials is not compromised } \\
\text { in my school }\end{array}$ & & Disagree \\
2 & $\begin{array}{l}\text { Students in my class can manipulate objects } \\
\text { in sciences, vocational and technical } \\
\text { science }\end{array}$ & .726 & Disagree \\
3 & $\begin{array}{l}\text { The used of ICT in enhancing student } \\
\text { centered learning is real in my school. }\end{array}$ & 1.55 & A g r e e \\
4 & $\begin{array}{l}\text { The school equipment to back up } \\
\text { innovation teaching and learning are up to } \\
\text { standard. }\end{array}$ & .698 & Disagree \\
$\begin{array}{l}\text { Student are given ample time to show case } \\
\text { the knowledge gained in a learning based on } \\
\text { school time table. }\end{array}$ & & .429 & Agree \\
We struggle to teach with the old and \\
dilapidated building, no innovation exist \\
with infrastructure \\
$\begin{array}{l}\text { The availability of project, laptops are small } \\
\text { in relation to the population of students }\end{array}$
\end{tabular}


Vol.8, Issue 7, pp.9-17, August 2020

Published by $\boldsymbol{E C R T D}-\boldsymbol{U K}$

Print ISSN: ISSN 2054-6351: Online ISSN: ISSN 2054-636X

The result in table 1 reveals that all 5 out of the 7 items measuring the extent to which innovation in curriculum is managed to achieve sustainable development in Ikwuano LGA in Abia State were below the mean cut off of 2.50 which was arrived at by summing the four-point scale of strongly agree (4) + agree (3) + disagree (2) and strongly disagree (1) divided by 4. Thus, response above 2.50 were favorable (agreed) response and response below 2.50 were tagged as unfavourable response (disagree). Item 2 had the highest unfavourable mean of 2.34 . Next is item 1 with $=2.31$. Next is item 7 with of 2.21. Next is item 4 with $=2.14$, next is item 6 with $=2.11$, while item 7 had positive mean of 2.51 while item 3 and 5 with favourable mean of 2.55 and 2.59 above the mean cut off which is agreed response. The grand mean of 2.37 summarily indicates that extent to which innovation in curriculum when managed to achieve sustainable development in Ikwuano LGA in Abia State is inadequate 2. To what extent is innovation in curriculum managed to achieve sustainable development from principals' perception?

Table 2. Mean rating on the extent to which science curriculum is well managed to achieve sustainable development from principals' perception.

\begin{tabular}{llllllll}
\hline S/N & \multicolumn{1}{c}{ ITEMS } & & SD & REMARKS \\
\hline 1 & $\begin{array}{l}\text { Regular supervision of my teacher is my upmost } \\
\text { concern. }\end{array}$ & 2.12 & .921 & Disagree
\end{tabular}

2 Finds allocated to procures materials for science 2.14

.726 Disagree technical are vocational studies is grossly inadequate

3 Most teacher lack the basic training to deliver the new 2.39

1.18 Disagree curriculum to teachers.

4 Regular training and retraining of teachers to adapt, the 2.23

.698 Disagree new curriculum is very effective.

5 There is inadequate manpower especially in areas of 2.59 technical vocational studies

6 Embezzlement of fund by stakeholders seem to reduce 2.09 .448 Disagree the level of (innovation in sciences.

.429 Agree

7 Poor attitude of teachers to adapt and adjust to 2.41 innovations affects the performance of students

.642 Disagree

Grand Mean 
The result in table 2 shows 6 out of the 7 item measuring the extent to which innovation in curriculum is managed to achieve sustainable development in Ikwuano LGA in Abia State from principals perception were below the mean cut off of 2.50.Item 7 had the highest unfavourable mean of 2.41, next is item 3 with 2.39, next item 4 with of 2.23 next is item 2 with of 2.14 , next is item 1 mean of 2.12 and item 6 with X of 2.09 while item 5 had a favorable X of 2.59 which is above the mean cut off of 2.50 . The grand mean of 2.27 summarily implies that the extent to which innovation in curriculum is managed to achieve sustainable development in Ikwuano LGA in Abia State from principals' perception is inadequate

\section{Hypothesis 1.}

There is no significant difference in the mean ratings of teachers and principals on the extent to which innovation in curriculum is managed to achieve sustainable development in Ikwuano LGA in Abia State

Table 3. T-test analysis on the mean ratings of teachers and principals on the extent to which innovation in curriculum is managed to achieve sustainable development in Ikwuano LGA in Abia State

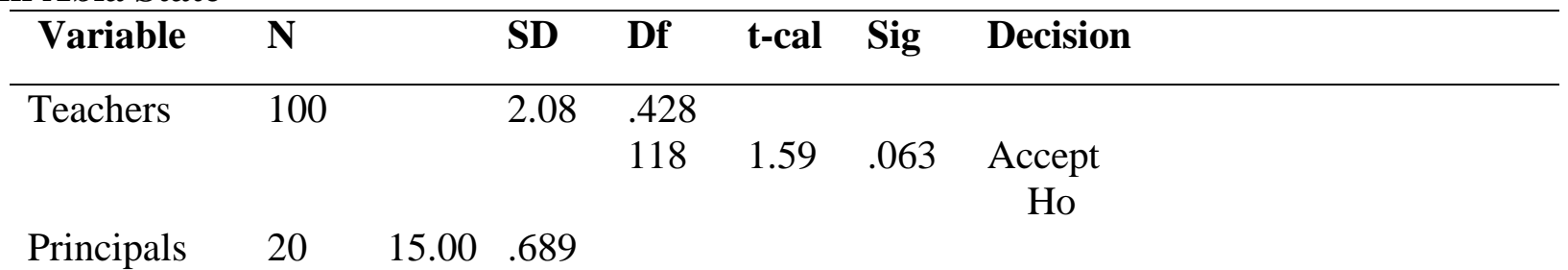

Significant at $\mathrm{P}<0.05$.

Table 3 reveals that the $t$-calculated value of 1.59 at $\mathrm{df}=118$ where $\mathrm{p}>0.05$. This indicates that there is no significant difference in mean ratings of teachers and principals on the extent to which innovation in curriculum is managed to achieve sustainable development in Ikwuano LGA in Abia State. hence the null hypothesis which states the there is no significant difference in mean ratings of teachers and principals on the extent to which innovation in curriculum is managed to achieve sustainable development in Ikwuano LGA in Abia State is therefore accepted.

\section{DISCUSSION OF FINDINGS}

The finding of this study reveals that the extent to which innovation in curriculum is managed to achieve sustainable development in Ikwuano LGA in Abia State from teachers perception is inadequate, the finding of this study is in line with the finding of Chaiemeke - Unorgu (2018) she discovered that the innovations in curriculum was not properly implementer, though a laudable initiative to cope with ever changing societal need lack proper implementation. The process stage is still in chaos since most instructional aids, equipment are grossly inadequate to drive home instructional objectives when teaching for example computers. 
The finding of this study reveals that the extent to which innovation in curriculum is managed to achieve sustainable development in Ikwuano LGA in Abia State from principals perception is inadequate, the findings of this study is supported by like (2017) he opined that the key players find it difficult coping with new curriculum factors such as poor training of teachers and re training of teachers, embezzlement of funds, inadequate manpower in the area to technical and vocational studies hence the new curriculum should not need as a pen and pencil initiation by the ministry of education.

The findings of this study reveals that there is no significant difference in mean ratings of teachers and principals on the extent to which innovation in curriculum is managed to achieve sustainable development in Ikwuano LGA in Abia State, the findings are in affirmation with Ahmadi and Lukman (2015) who carried out a survey effective implementation of New Secondary School curriculum in Nigeria they opined that to a large extent the secondary school curriculum is grossly inadequate to compete favourable globally, they suggested that there need to review the status quo of secondary school curriculum in order to consolidate further, hence the new basic education programme needs funding and re training of teachers on the area of human capital development for the actualization of sustainable developmental goals.

In other words where as the principals put into practice the findings of this research study into the school system, the management will not only be made easy, but will improve performance in both school management and teachers work towards achieving goals.

\section{CONCLUSION}

Science is regarded as the mother of all subject, the new curriculum innovation that includes technical and vocational education when implemented optimally is capable of transforming our economy. All sector of the economy will have trained and skilled manpower to drive home production and increase our economy like leading economic of the world. The certification emphasis of the 6334 has failed in increasing labour and productivity hence if we are competite globally through the innovation curriculum of 934, all stakeholder may address factors such as funding, training and re-training of teachers, provision of instruction materials and employ more academically sound teachers. Also, there would be quality sustainability and development in the area.

\section{Recommendation:}

The recommendations of this study are

1. A re-evaluation of the new curriculum should be doe, if other to see the strength and weakness of the reform with a view of preferring lasting solutions.

2. Government owing teacher should be made to face legal sanctions.

3. Teacher should be sent outside the country to learn methodology is in driving ......... the objectives of the new curriculum.

4. Quarterly training of searchers in sciences, technical and vocational studies should be norm.

5. Adequate internal and external monitoring team should be upheld. 
Vol.8, Issue 7, pp.9-17, August 2020

Published by ECRTD- $\boldsymbol{U K}$

Print ISSN: ISSN 2054-6351: Online ISSN: ISSN 2054-636X

6. Students should be made to produce things on a term basis via technical and vocational studies.

\section{REFERENCES}

Ahmadi, A.A and Lukman, J.A (2015) issues and prospects of effective implementation of New Secondary School curriculum in Nigeria, journal of Education and practice Vol. 6 (34) 29-37.

Ayeni, M.A and Dada, M. A (2011) An exploration into the education innovation in Nigeria in the last two decades. Journal of Emerging trends in Education Research and policy studies Vol. 2(4) 199-205.

Ebenuwa-Okoh, E.E. (2012). Correlates of marital adjustment among married persons in Delta state of Nigeria: Implications of Guidance and Counselling Unpublish $\mathrm{PhD}$ thesis submitted to the Department of Educational psychology and Curriculum Studies of the University of, Benin City

Ike, P (2017 problem and prospect secondary Education in Nigeria. International Journal of Educational Evaluation Vol. 3 (1) 44

Kebbi, J. A \& Adediran, A. A. (2013). Implementation of universal basic educational system in secondary schools' level. International Journal of Innovation Education Research, $1(2), 10-16$

Olori, T. (2005). Lack of resources threatened universal basic education. Retrieved from http://www.newsfromafrica.org/newsafrica/article/art-9114.html.

Ivowi, U.M.O. (2007).Telescoping curriculum and Instruction in Nigeria. WCCI 4th Biennial seminar lecture, held at NERDC, Sheda-Abuja on the 23 October 2007.

Obima, A.(2006). The Nigerian Education times, No12 November -December, 2006.

Offorma,G.C.(2005).3rd Biennial seminar lecture held in federal college of education ,Kano on 25th October he use and the teachers 'guide and the curriculum were not properly circulated.

Moyinoluwa, T.D (2015) implementation of the revised 9 year Basic Education curriculum (BEC) in the North central Nigeria. A case stud of Bende State. Journal of Research and method in Education Vol. 3 (3) 67-72.

Ofsted (2008) Curriculum Innovation in Schools Journal of Sted Raising Standards Improving Lives Vol 1,5-22.

Otaru, B.M (2015) teachers perception on the implementation of a 9 years basic education curriculum implementation in Edo State. British Journal of Education Vol. 3(8) 20-27.

Oyonwi, E.O (2012) science curriculum in nation in Nigeria senior secondary school challenges and prospects. The Nigeria Academic forum Vol. 22 (1) 1-5.

Unogu - Mc (2018) planned Educational changes and innovation process Nigeria. Evaluation of universal basic education. Vol II (1) 71.89. 